\title{
中程度の高温環境下における知的生産性に関する被験者実験 SUBJECTIVE EXPERIMENTS ON PRODUCTIVITY UNDER MODERATELY HOT ENVIRONMENT
}

\author{
西原直枝*, 田辺新一** \\ Naoe NISHIHARA and Shin-ichi TANABE
}

\begin{abstract}
Subjective experiments were conducted in a climatic chamber to evaluate the effect of thermal environment on productivity. Chamber was conditioned at operative temperatures of $25.5^{\circ} \mathrm{C}, 28^{\circ} \mathrm{C}$, or $33^{\circ} \mathrm{C}$. The effects of thermal environment on task performance were modest and contradictory among the task types. According to the evaluation of fatigue feeling, the subjects most complained of mental fatigue at $33^{\circ} \mathrm{C}$. The cerebral blood oxygenation was monitored by the near infrared spectroscopy. Concentration of total and oxygenated hemoglobin increased and that of deoxygenated hemoglobin decreased at $33^{\circ} \mathrm{C}$. Evaluation of fatigue feeling and monitoring cerebral blood oxygenation might be applied to the measurement of productivity.
\end{abstract}

Keywords : Productivity, Task performance, Fatigue feeling, Near infrared spectroscopy, Thermal environment 知的生産性, 作業効率, 疲労感, 近赤外線酸素モ二夕, 温熱環境

\section{1.はじめに}

近年, オフィスや学校等の計画や設計においては, 在室者の快適 性・健康性を求めるだけでなく, さらに知的生産性の向上を求める

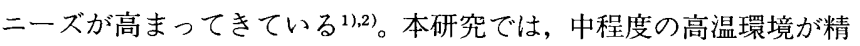
神作業を中心とした知的生産性に及ぼす影響について評価すること を目的とし，被験者実験を行った。

生産性は, Parsons ${ }^{3}$ により,「活動により得られる, ある組織の目 標に対する作業効率」であると定義されている。Parsonsは, 温熱環 境と生産性の関係について, 温熱環境が, 人間の心理的および生理 的過程に影響を与え, それが活動, 作業効率, さらに生産性に影響 を与えると位置づけている。

米国ではASHRAE (米国暖房冷凍空調学会)を中心として, Dorgan ら ${ }^{4)}$, Fisk と Rosenfeld ${ }^{5}$ 。, 欧州ではWyon ら 室内環境との関連について, 経済的なコストを試算し評価する研究 が行われている。これらの研究により, 作業者に対する人件費が空 調設備等を含む建物に対するコストよりも高いことが示され, 室内 環境を改善することで作業者の知的生産性が上がれば, 経済的にも 効率的であることが報告されている。これらの生産性の試算には, 呼吸器系疾患による欠勤率等から評価を行う場合が多かった。一方, 室内環境を改善することにより，作業の正確さやスピード等を含め た作業成績, 心理量, 生理量に与える影響については, 実験室実験 による検討が行われてきている。Heath と Mendell ${ }^{7}$ は, 室内環境の 質と生産性についてのレビューを行い，十分な実験計画のもと行わ れた研究において, 室内空気質や光環境が悪いと, 作業成績等の作
業効率に負の影響を与えるという研究事例を挙げている。しかし， Heath と Mendell は, 室内の温熱環境要素が作業効率に与える影響 については，まだ決定的な知見が得られていないと報告している。 温熱環境全般に関する初期の研究としては, Vernon $^{8)}$ がブリキ工 場における季節による生産高の変化について, Chrenko'が高温に よる事故率の増加について報告し, 生産高と事故率が温熱条件に よって大きく影響されることが明らかにされている。これらの結果 は, フィールド調査によるものであるため，温熱環境だけでなく生 産性に影響を与える多くの要因を含んでおり，温熱環境が生産性に どのようなメカニズムで影響を与えているのかについては，不明な 点が多い。一方，フィールド調査だけでなく，温熱環境に関する実 験室実験が行われている。精神作業を中心とした知的生産性と温熱 環境に関するレビューでは, Parsons ${ }^{3)} \mathrm{Wyon}^{10)}$ が, 温熱環境は知 的生産性に何らかの形で影響を与えると報告しているが, Lorsh ${ }^{11)}$ やSundstrom ${ }^{12}$ が指摘するように，それらの結果は一致しておら ず，統一した見解が得られているとは言い難い。その原因として， McIntyre ${ }^{13)}$ が指摘しているように, 覚醒やモチベーション等の心理 的な要因が作業成績等に関係していることが考えられる。単に精神 作業の成績からだけでは，温熱環境要素が知的生産性に与える影響 を評価するのが難しい。

本研究では, 中程度の高温環境が知的生産性に与える影響を調べ る為に被験者実験（第一被験者実験）を行った。コンピュー夕を用 いた複数の作業を被験者に課し，作業成績による評価を行うととも に, 心理量, 生理量および作業時の疲労状態を測定し総合的に評価

\footnotetext{
* 早稲田大学理工学部

日本学術振興会特別研究員 ·博上 (学術)

** 早稲田大学理工学部建築学科 教授. 工博
}

JSPS Research Fellow, Waseda University, Ph. D.

Prof., Dept. of Architecture, Waseda University, Dr. Eng. 
した。

従来の研究では，知的生産性を测定するために，作業を課した時 の作業成績に着目することが多く, 疲労状態に重点をおいた研究は 少ない。本研究では, 疲労状態を測定する為に, 日本産業衛生協会 産業疲労研究会作成「自覚症状しらべ」14)を用いた疲労感調查を行っ た。疲労状態については, 労働科学研究所の吉竹らにより労働現場 における研究が行われたが，温熱環境等の室内環境要素や知的生産 性との関係については検討されていない。

また，近年，近赤外線分光により生体組織の酸素化状態を無侵襲 かつ連続的に测定できるようになり，快適性評価や精神作業中の脳 活動状態の評価への応用が期待されている15),16),17)。本研究では, 被 験者実験（第二被験者実験）を行い，中程度の高温環境下における 精神作業時の脳内酸素代謝について，近赤外線酸素モ二夕を用いて 測定した。中枢神経活動をモニ夕することにより，知的生産性を評 価する上での新たな知見を得るための手法としての有効性について 検討を行った。

\section{2. 第一被験者実験方法 \\ （1）実験条件}

実験は2000年11月16日～12月19日に，早稲田大学温熱環境室に設 置された人工気候室にて行った。実験では，熱的中立状態として人 工気候室の作用温度を $25.5^{\circ} \mathrm{C}$ に設定した条件，より高温の環境とし て作用温度を $28^{\circ} \mathrm{C}, 33^{\circ} \mathrm{C}$ に設定した 2 条件を加えて計 3 条件とし， コンピュータを用いた複数の作業を被験者に課した。上記の 3 条件 以外に作業の学習効果を除くため, 実験の第 1 回目に練習条件を設

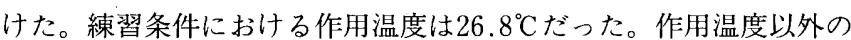
環境条件は一定とし，相対湿度 $44 \% \mathrm{RH}$ ，静稳気流に制御した。実験 服の着衣量はサーマルマネキン18)測定により0.76cloだった。図 1 に実験室の平面図を，表 1 に実験条件を示す。以後実験条件は，作 用温度 $25.5^{\circ} \mathrm{C}$ 条件を $25.5^{\circ} \mathrm{C}$, 作用温度 $28^{\circ} \mathrm{C}$ おび $33^{\circ} \mathrm{C}$ 条件も同様に, 各々 $28^{\circ} \mathrm{C}, 33^{\circ} \mathrm{C}$ と略す。

\section{(2) 被験者}

被験者は健康な大学生年齢の男女各 20 名, 計 40 名とした。被験者 には，正当な報酬に加えて，作業に取り組む動機のレベルを一定に 保つために成績優秀者にボーナスを支払った。曜日や時間による影 響を極力少なくするために，被験者は 1 週間間隔で 4 条件とも同じ 曜日，時間帯の実験に参加した。図 2 に実験風景を示寸。被験者の 身体的特徵を表 2 に示す。

\section{（3）実験手順}

眓 3 にタイムスケジュールを示す。被験者は実験服に着替えた後, 人工気候室に入室し，約 90 分間の曝露実験を開始した。大室して30 分間椅座安静にした後，10分間の加算テスト， 5 分間のポジショ二 ング作業, テキストタイピング作業, 約15分の Walter Reed Perfor-

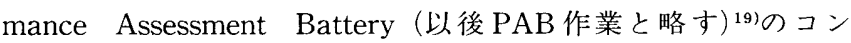
ピュータを用いた作業課題を順に実施した。表 3 に作業一覧を示す。 自覚症状しらべは，人工気候室入室し椅座位安静30分後に「作業前」 の申告を行い, 全作業終了後に「作業後」の申告を行った。また， 室内の温熱環境および空気の新鮮度についての主観的評価について は，作業前および作業後の申告に加え各コンピュータ作業後にも申 告を行った。申告を行う時間も含め, 作業と作業の間に 5 分間の休
悡を取った。図 4 に温熱環境および空気の新鮮度に関する申告用紙 を示す。

「自鸴症状しらべ」は, 疲労感を主観的に評価する手法である。2002 年に「自覚症状しらべ」を改訂した新版「自覚症しらべ」が提案さ れている ${ }^{20)}$ が, 従来の方式は, 労働科学・人間工学の分野や労働環境 の現場で長年利用されており, 既往研究デー夕の蓄積が多く実績が ある。このため,「自覚症状しらべ」は現場用に開発されたものでは あるが，今回の研究ではこれを用いた。自覚症状しらべの質問紙は， 全 3 群合計 30 項目で構成されている。各群の内容は，I群の 10 項目 として「眠気とだるさ」を中心とする疲労一般の訴え，II群の 10 項 目として「注意集中の困難さ」を示す作業意欲減退を中心とする心 的症状についての訴之，III群の10項目として「局在した身体の違和 感」で体の特定部位に現れる心身症的訴え，である。被験者は，各 症状のうち該当する項目に○を，該当しない項目にメを記入する。 自覚症状しらべの症状項目を表 4 に示寸。症状の訴之率は吉竹らの 方法に準拠し，次式に基づき算出した。なお，30項目全体に対する 訴え率を「総合訴え率」と定義した。

$$
\text { 症状訴之率 }(\%)=\frac{\text { 対象集団の総訴之数 }(\lceil\bigcirc 」 の \text { 総数 })}{\text { 項目の数 } \times \text { 対象集団ののべ数 }} \times 100
$$

吉竹らは，自覚症状しらべの各症状群間の順序関係は，一般型 ( I > III > II ), 精神作業・夜勤型（I > II > III）, 肉体作業型（III > I > II）の 3 種類に大別され, 総合訴之率が高い場合に精神作業・ 夜勤型が生じやすいと報告した。本研究では，中程度の高温環境が 疲労感に与える影響について調べるために, 自覚症状しらべを用い, 上記 $3 つ の$ 症状群がどのような出現をするかを分析した。

\section{(4) 統計解析衫}

テキストタイピング及び PAB 作業の作業成績は 1 分間に正確な 作業を行った数を用いて評価した。なお, PAB 作業のうち, Interval Production テストでは, 被験者が 1 秒間であると判断した実際の時 間を測定し評価した。申告結果および作業量について，環境条件間 の比較は最小有意差法を，男女間の比較には対応のない $\mathrm{t}$ 検定を用 いた。なお，環境条件間の比較は練習条件を除いて検定を行った。

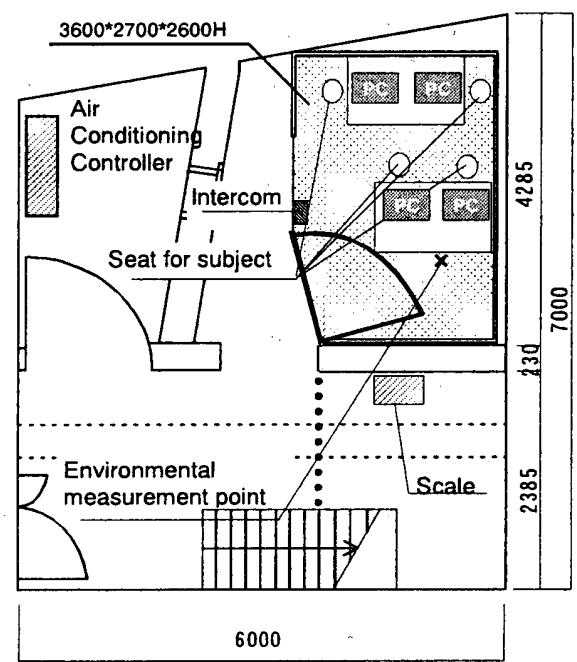

図 1 温熱環境室平面図

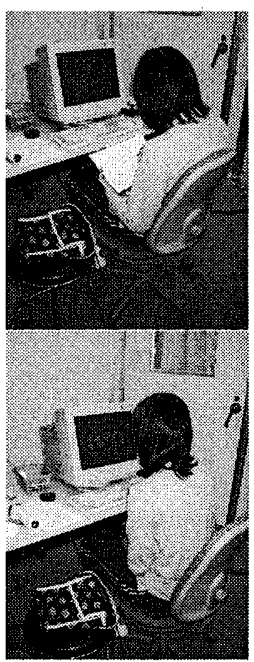

図 2 被験者実験風景 
表 1 実験条件

\begin{tabular}{c|c|c|c|c}
\hline Condition & $\begin{array}{c}\text { Air Temp. } \\
{\left[{ }^{\circ} \mathrm{C}\right]}\end{array}$ & $\begin{array}{c}\text { Globe Temp. } \\
{\left[{ }^{\circ} \mathrm{C}\right]}\end{array}$ & $\begin{array}{c}\text { Operative } \\
\left.\text { Temp. [ }{ }^{\circ} \mathrm{C}\right]\end{array}$ & $\begin{array}{c}\text { Relative } \\
\text { Humidity [\%] }\end{array}$ \\
\hline \multirow{2}{*}{ 練習 } & 26.6 & 27.0 & 26.8 & 43 \\
& $(0.43)$ & $(0.31)$ & $(0.37)$ & $(0.7)$ \\
\hline \multirow{2}{*}{$25.5^{\circ} \mathrm{C}$} & 25.4 & 25.6 & 25.5 & 46 \\
& $(0.87)$ & $(0.83)$ & $(0.83)$ & $(0.6)$ \\
\hline \multirow{2}{*}{$28^{\circ} \mathrm{C}$} & 27.9 & 28.1 & 28.0 & 47 \\
& $(0.22)$ & $(0.20)$ & $(0.19)$ & $(0.6)$ \\
\hline \multirow{2}{*}{$33^{\circ} \mathrm{C}$} & 33.0 & 32.9 & 32.9 & 40 \\
& $(0.53)$ & $(0.51)$ & $(0.52)$ & $(1.1)$ \\
\hline
\end{tabular}

表 2 被験者の身体的特徵

\begin{tabular}{c|c|c|c|c|c|c}
\hline Sex & $\begin{array}{c}\text { Num } \\
\text { ber }\end{array}$ & $\begin{array}{c}\text { Age } \\
\text { [year] }\end{array}$ & $\begin{array}{c}\text { Height } \\
{[\mathrm{cm}]}\end{array}$ & $\begin{array}{c}\text { Weight } \\
{[\mathrm{kg}]}\end{array}$ & $\begin{array}{c}\text { Body } \\
\text { Surface } \\
\text { Area* } \\
{\left[\mathrm{m}^{2}\right]}\end{array}$ & $\begin{array}{c}\text { Rohrer } \\
\text { Index** } \\
{[-]}\end{array}$ \\
\hline Male & 20 & $\begin{array}{c}22.1 \\
(1.71)\end{array}$ & $\begin{array}{c}173.2 \\
(5.67)\end{array}$ & $\begin{array}{c}60.3 \\
(7.38)\end{array}$ & $\begin{array}{c}1.73 \\
(0.12)\end{array}$ & $\begin{array}{c}116.0 \\
(11.8)\end{array}$ \\
\hline Female & 20 & $\begin{array}{c}22.0 \\
(2.40)\end{array}$ & $\begin{array}{c}158.4 \\
(5.45)\end{array}$ & $\begin{array}{c}49.3 \\
(5.08)\end{array}$ & $\begin{array}{c}1.49 \\
(0.09)\end{array}$ & $\begin{array}{c}124.1 \\
(12.2)\end{array}$ \\
\hline
\end{tabular}

*Calculated by Takahira's Equation : $\mathrm{A}=72.46 \mathrm{~W}^{0.425} \times \mathrm{H}^{0.725}$

**Rohrer Index $=\mathrm{W} / \mathrm{H}^{3} \times 10^{7}$

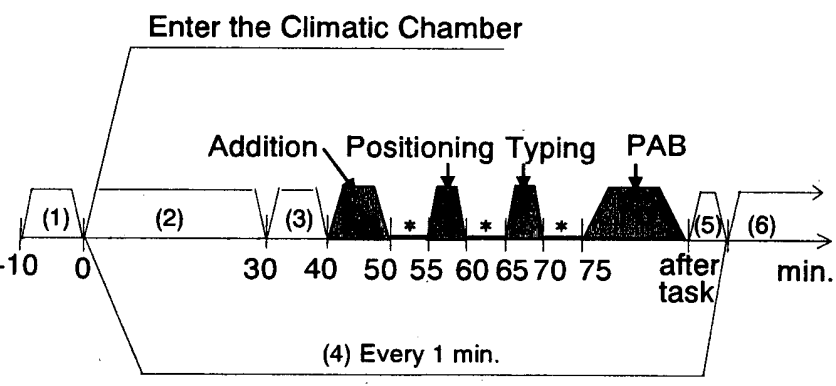

(1) Change Clothes, Weight

(2) Staying Sedentary, Questionnaire, Oral Temperature

(3) Flicker Test, Evaluation of Subjective Symptom of Fatigue, Vote

(4) Physiological and Environmental Measurements

(5) Vote, Evaluation of Subjective Symptom of Fatigue, Flicker Test

(6) Change Clothes, Weight

* Vote, Intermission

$$
\text { 図3タイムスケジュール }
$$

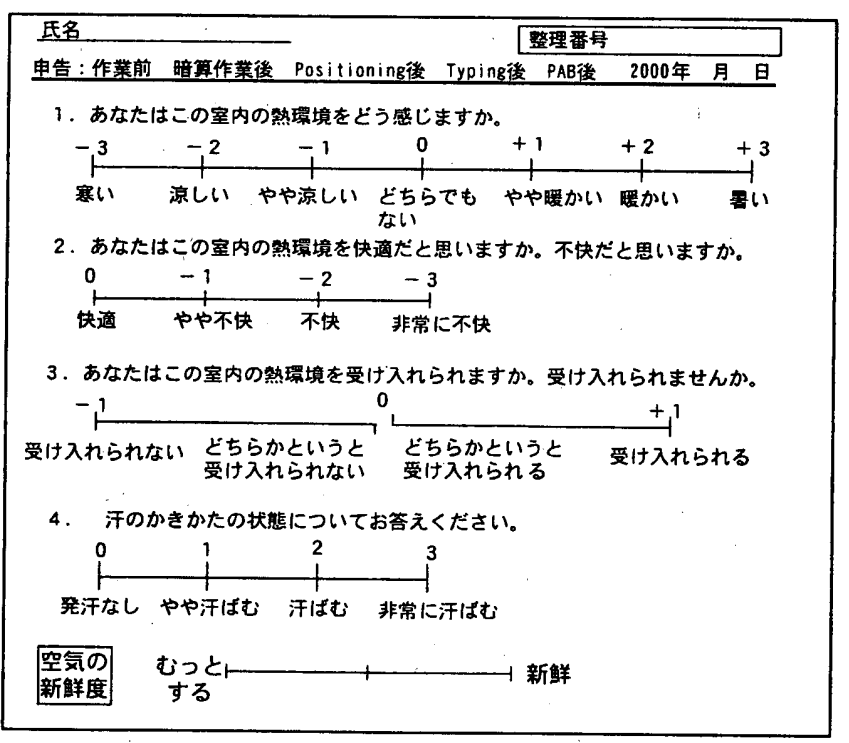

図 4 温熱環境および空気の新鮮度に関する申告
表 3 作業一覧

\begin{tabular}{|c|c|c|}
\hline \multicolumn{2}{|r|}{ 加算テスト } & $\begin{array}{l}\text { 横に並んだ1析の数字を足して答の下1析を次々と記入 } \\
\text { する作業。 }\end{array}$ \\
\hline \multicolumn{2}{|c|}{ ポシショニング作業 } & 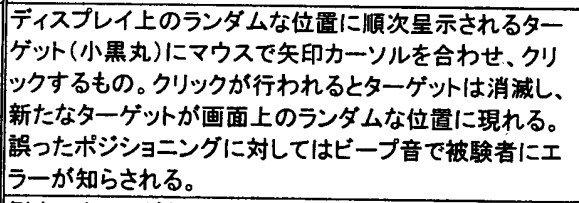 \\
\hline \multicolumn{2}{|c|}{ テキストタイピング } & 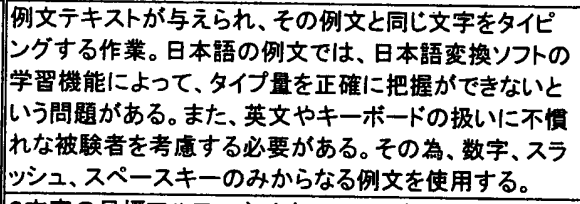 \\
\hline \multirow{7}{*}{ PAB } & $\begin{array}{l}\text { Two-letter } \\
\text { search }\end{array}$ & $\begin{array}{l}\text { 2文字の目標アルファベットとアルファベットの文字列が } \\
\text { |画面に表示され、文字列中に二つの目標文字があるか } \\
\text { ないかを判断する作業。 }\end{array}$ \\
\hline & $\begin{array}{l}\text { Four choice } \\
\text { serial reaction } \\
\text { time }\end{array}$ & $\begin{array}{l}\text { テンキーの1、2、4、5に対応する4つのボックスが表示 } \\
\text { され、そのボックスの中のーつに光が点滅する。光が点 } \\
\text { 滅しているボックスに対応する数字を入カする作業。 }\end{array}$ \\
\hline & $\begin{array}{l}\text { Interval } \\
\text { production }\end{array}$ & $\begin{array}{l}\text { 時計の秒針が表示され、自らが1秒だと感じる間隔でボ } \\
\text { タンを押して秒針を動かす作莱。作莱中時計などは参 } \\
\text { 照しない。 }\end{array}$ \\
\hline & Manikin & $\begin{array}{l}\text { 画面に人体とOもしくは口の図形が人体の周囲および } \\
\text { 人体の左右の手に表示され、人体を囲んでいる图形 } \\
\text { と、同じ図形を持っている方の手の左右を答える作莱。 }\end{array}$ \\
\hline & $\begin{array}{l}\text { Code } \\
\text { substitution }\end{array}$ & $\begin{array}{l}\text { 数字とアルファベットの対応表が与えられる。その後、ア } \\
\text { ルファベットが画面に表示され、それに対伛する数字を } \\
\text { 入力する作業。 }\end{array}$ \\
\hline & $\begin{array}{l}\text { Matching to } \\
\text { sample }\end{array}$ & $\begin{array}{l}\text { まずサンプルの図形が画面に表示される。その後、2つ } \\
\text { の図形が並んで表示され、サンプルと同一の図形を選 } \\
\text { 択する作業。 }\end{array}$ \\
\hline & $\begin{array}{l}\text { Running } \\
\text { memory }\end{array}$ & $\begin{array}{l}\text { 1から3の数字が1文字ずつ次々と画面上に表示され、 } \\
\text { 1つ前に表示された数字をキーボードよ入カする。 }\end{array}$ \\
\hline
\end{tabular}

表 4 自覚症状しらべの症状項目 ${ }^{14}$

\begin{tabular}{|c|c|c|}
\hline I 群 & II 群 & III 群 \\
\hline 頭がおもい & 考えがまとまらない & 頭がいたい \\
\hline 全身がだるい & 話をするのがいやになる & 肩がこる \\
\hline 足がだるい & いらいらする & 䁏がいたい \\
\hline あくびがでる & 気がちる & いき苦しい \\
\hline 頭がぼんやりする & 物事に熱心になれない & 口がかわく \\
\hline ねむい & $\begin{array}{l}\text { ちょっとしたことが思い } \\
\text { 出せない }\end{array}$ & 声がかすれる \\
\hline 目がつかれる & することに間違いが多くなる & めまいがする \\
\hline 動作がぎこちない & 物事が気にかかる & $\begin{array}{l}\text { まぶたや筋肉がピ } \\
\text { クピクする }\end{array}$ \\
\hline 足もとがたよりない & きちんとしていられない & 手足がふるえる \\
\hline 横になりたい & 根気がなくなる & 気分がわるい \\
\hline
\end{tabular}

また，空気の新鮮度に関する申告結果については，加算，ポジョ ニング，テキストタイピング作業後における計 3 回の平均申告值を 「作業後」のデータとし, 作業前後の比較を行った。作業前後の比較 は対応のある $\mathrm{t}$ 検定を用いた。グラフ中の**は $\mathrm{p}<0.01, *$ * $\mathrm{p}<$ 0.05 , 十は $\mathrm{p}<0.1$ を示多。

\section{3. 第一被験者実験結果・考察}

\section{(1) 温熱環境および空気の新鮮度に関する申告}

表 5 に, 作業前から PAB 作業後まで全 5 回の温熱環境について の平均申告値を環境条件ごとに示す。男女間の比較では, 温冷感, 発汗感覚の $25.5^{\circ} \mathrm{C}$ 条件で有意に女性の方が低い値となった $(\mathrm{p}<$

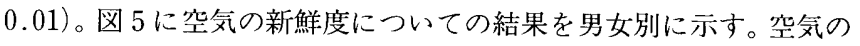


表 5 温熱環境についての申告結果（平均値士標準偏差）

\begin{tabular}{c|c|c|c|c|c}
\hline \multicolumn{2}{c|}{} & 温椧感 & 快不快感 & 熱的受容度 & 発汗感覚 \\
\hline \multirow{5}{*}{ Male } & $25.5^{\circ} \mathrm{C}$ & $0.1 \pm 0.83$ & $-0.4 \pm 0.33$ & $0.5 \pm 0.33$ & $0.4 \pm 0.37$ \\
\cline { 2 - 7 } & $28^{\circ} \mathrm{C}$ & $1.2 \pm 0.69$ & $-0.8 \pm 0.59$ & $0.1 \pm 0.44$ & $0.8 \pm 0.58$ \\
\cline { 2 - 7 } & $33^{\circ} \mathrm{C}$ & $2.5 \pm 0.49$ & $-2.2 \pm 0.66$ & $-0.6 \pm 0.38$ & $1.9 \pm 0.66$ \\
\hline \multirow{5}{*}{ Female } & $25.5^{\circ} \mathrm{C}$ & $-0.6 \pm 1.03$ & $-0.5 \pm 0.58$ & $0.5 \pm 0.44$ & $0.1 \pm 0.17$ \\
\cline { 2 - 7 } & $28^{\circ} \mathrm{C}$ & $1.1 \pm 0.78$ & $-0.7 \pm 0.55$ & $0.2 \pm 0.44$ & $0.6 \pm 1.29$ \\
\cline { 2 - 7 } & $33^{\circ} \mathrm{C}$ & $2.5 \pm 0.63$ & $-1.9 \pm 0.76$ & $-0.5 \pm 0.41$ & $1.6 \pm 0.99$ \\
\hline
\end{tabular}

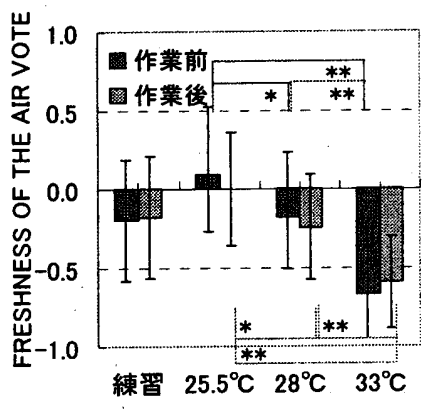

男性

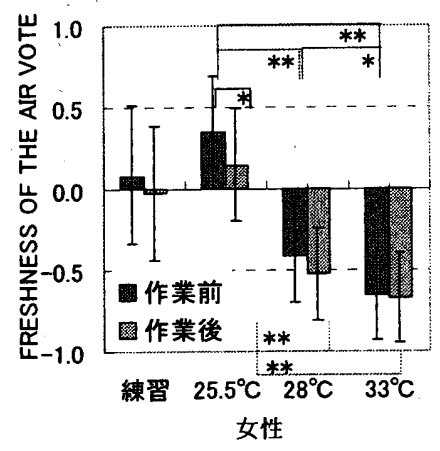

女性
図 5 空気の新鮮度申告值結果

新鮮度に対し「新鮮」を 1 ，「むっとする」をー 1 とし解析した。男 女ともに $33^{\circ} \mathrm{C}$ 条件の方が $28^{\circ} \mathrm{C}$ 抢よび $25.5^{\circ} \mathrm{C}$ 条件よりも空気の新鮮度 が有意に低下し，むっとする側の結果となった。

\section{（2）作業成績}

女性では，全ての作業課題について，環境条件間で作業量に有意 な差が認められなかった。男性で，環境条件間で有意な差が認めら れた作業は，テキストタイピング作業および Four choice 作業のみ であった。図6，図７にテキストタイピング作業拉よび Four choice 作業の作業成績を示す。男性のテキストタイピング作業では, $25.5^{\circ} \mathrm{C}$ 条件が $28,33^{\circ} \mathrm{C}$ 条件よりも有意に作業量が少なかった $(\mathrm{p}<0.05)$ 。 また, Four choice 作業では, $33^{\circ} \mathrm{C}$ 条件の方が $28^{\circ} \mathrm{C}$ 条件より有意に少 なかった $(\mathrm{p}<0.05)$ 。それ以外の作業では，環境条件間で有意差は 認められなかった。

知的生産性を評価する際，作業成績による評価では多くの作業に 対し温熱環境による有意な差が認められなかった。また，男性にお いて環境条件による有意差が怨められた作業に関しても，最も作業 効率が低下した環境条件は,テキストタイピング作業では $25^{\circ} \mathrm{C}$ 条件, Four choice 作業では $33^{\circ} \mathrm{C}$ 条件であり, 統一した見解は得られな かった。Pepler と Warner ${ }^{21}$ は, 室温の異なる部屋における学習効率

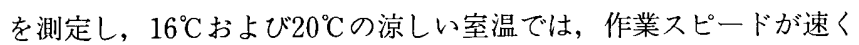
なりエラー率が有意に高かったが, $30^{\circ} \mathrm{C} や 33^{\circ} \mathrm{C}$ の高い室温では学習 効率における有意な差は認められなかったと報告している。 Sundstrom ${ }^{12}$ は, 精神作業と室温との関係について研究レビューを 行い，精神作業成績は一般的に熱による影響をほとんど受けないと

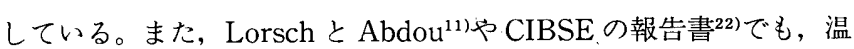
熱環境が精神作業に与える影響については，統一した結果が得られ ていないと報告している。精神作業を対象とする場合, 作業成績の みでは評価が難しいと考えられる。

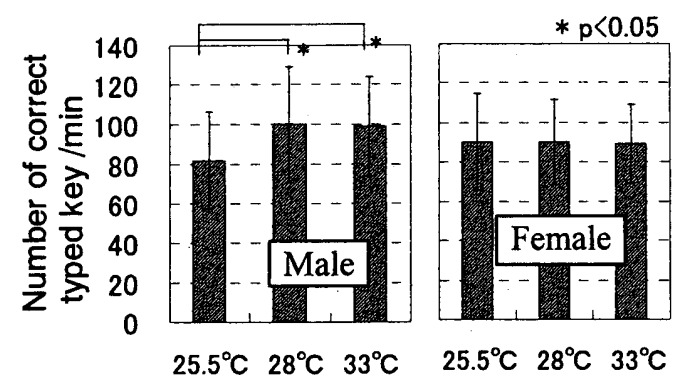

図 6 テキストタイピング

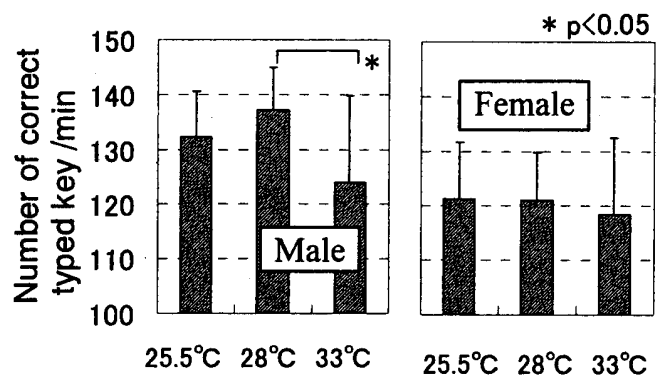

図 7 Four Choice (PAB 作業)

\section{(3) 疲労感}

図 8 に作業前および作業後の自覚症状総合訴え率を示す。作業前 および作業後の総合自覚症状の訴之率は, 男女ともに, $33^{\circ} \mathrm{C} か ゙$ 最も 高く, 次いで $28^{\circ} \mathrm{C}, 25.5^{\circ} \mathrm{C} の$ 順だった。作業環境の作用温度が熱的 中立状態より高温になることにより, 自覚症状の総合訴之率が高く なることが示唆された。作業前の方が作業後よりも, 環境条件間に おける訴え率の差が大きかった。

症状群別の訴之率の順序関係を調べた。表 6, 表 7 に各症状群ご との訴之率を示す。作業前は, $25.5^{\circ} \mathrm{C}$ 条件, $28^{\circ} \mathrm{C}$ 条件は, 男女とも に I > III > II の順であり, 疲労の一般型であったが, $33^{\circ} \mathrm{C}$ 条件では, 男女ともに I > II >IIIの順となり, 精神作業・夜勤型の疲労感を生 じた。II群の疲労訴之率は，作業環境が高温になるほど高かった。 作業後は，男性では，全ての条件において I > II >IIIの順となり， 精神作業・夜勤型となった。女性では, $25.5^{\circ} \mathrm{C}, 28^{\circ} \mathrm{C}$ 条件では I > III > IIの順であり, 疲労の一般型であったが, $33^{\circ} \mathrm{C}$ 条件では I > II > IIIの順となり，精神作業・夜勤型の疲労感となった。
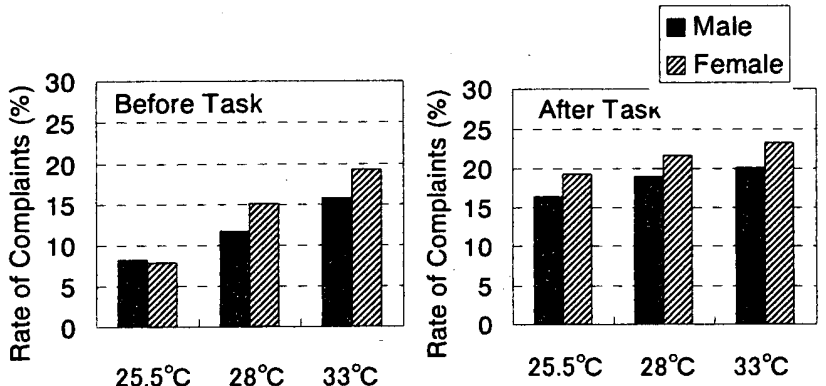

図 8 自覚症状しらべ総合訴之率 
表 6 作業前後の訴之率の条件別比較（男性）

\begin{tabular}{c|c|c|c|c|c}
\hline & 条件 & I群 & II群 & III群 & 群間順序比較 \\
\hline \multirow{4}{*}{ 作業前 } & $25.5^{\circ} \mathrm{C}$ & 15.5 & 3.5 & 5.5 & I > III > II \\
\cline { 2 - 6 } & $28^{\circ} \mathrm{C}$ & 23.0 & 5.0 & 7.0 & I > III > II \\
\cline { 2 - 6 } & $33^{\circ} \mathrm{C}$ & 24.0 & 12.0 & 11.5 & I $>$ II $>$ III \\
\hline 作業後 & $25.5^{\circ} \mathrm{C}$ & 21.5 & 14.0 & 13.5 & I > II > III \\
\cline { 2 - 6 } & $28^{\circ} \mathrm{C}$ & 28.0 & 15.5 & 13.5 & I > II > III \\
\cline { 2 - 6 } & $33^{\circ} \mathrm{C}$ & 24.5 & 21.5 & 14.5 & I > II > III \\
\hline
\end{tabular}

表 7 作業前後の訴之率の条件別比較（女性）

\begin{tabular}{|c|c|c|c|c|c|}
\hline & 条件 & I群 & 群 & III群 & 群間順序比較 \\
\hline \multirow[t]{3}{*}{ 作業前 } & $25.5^{\circ} \mathrm{C}$ & 16.5 & 1.5 & 5.5 & I $>$ III $>$ II \\
\hline & $28^{\circ} \mathrm{C}$ & 26.5 & 8.0 & 11.0 & I $>$ III $>$ II \\
\hline & $33^{\circ} \mathrm{C}$ & 32.0 & 14.0 & 12.0 & I $>$ II $>$ III \\
\hline \multirow[t]{3}{*}{ 作業後 } & $25.5^{\circ} \mathrm{C}$ & 31.5 & 12.5 & 14.0 & I $>$ III $>$ II \\
\hline & $28^{\circ} \mathrm{C}$ & 31.5 & 15.0 & 18.5 & I $>$ III $>$ II \\
\hline & $33^{\circ} \mathrm{C}$ & 34.0 & 19.0 & 16.5 & I $>$ II $>$ III \\
\hline
\end{tabular}

4. 第二被験者実験一近赤外線酸素モニタを用いた評価一

(1) 実験方法

中程度の高温環境下における精神作業時の脳内酸素代謝を測定す ることを目的とし, 近赤外線酸素モニ夕を用いた被験者実験を行っ た。被験者は, 健康な大学生年龄の男性 6 名とした。実験は2001年 3 月 21 日〜同年 4 月 13 日に，早稲田大学温熱環境室に設置された人 工気候室にて行った。室内の作用温度を $25^{\circ} \mathrm{C}, 33^{\circ} \mathrm{C}$ 計 2 条件に設 定し，第一被験者実験と同様にコシピュータを用いた複数の作業を 被験者に課した。なお，作業の学習効果を除くため，実験の第 1 回 目に作用温度 $25^{\circ} \mathrm{C}$ で練猊条件を設けた。表 8 に実験条件を，表 9 に 被験者の身体的特徴を示す。

実験方法は，第一被験者実験にほぼ準拠したが, フリッカ一值の 測定を行わずに，近赤外線酸素モニ夕による測定を加えた。図 9 に 近赤外線酸素モニ夕（浜松ホトニクス NIRO-300）を示す。測定プ ローブは，半導体レーザーを光源とした近赤外線照射プローブおよ び光検出プローブからなる。生体組織を通った光の吸収変化を測定 し, Modified Beer-Lambert 則に基づき，へモグロビンの酸素濃度 変化（単位： $\mu \mathrm{M}=10^{-6} \mathrm{~mol}$ ) を計算することができる ${ }^{23)}$

四10に被験者実験風景を示す。近赤外線酸素モ二タの測定プロー ブを左右前額部に設置し測定を行った。実験中 2 秒毎に脳内酸素化 へモグロビン濃度変化量 $\left(\Delta \mathrm{O}_{2} \mathrm{Hb}\right)$ および脱酸素化へモグロビン濃 度変化量 $(\Delta \mathrm{HHb})$ を測定した。また，総へモグロビン濃度変化 $(\Delta$ total $\left.\mathrm{Hb}=\Delta \mathrm{O}_{2} \mathrm{Hb}+\Delta \mathrm{HHb}\right)$ を算出した。実験条件間の平均値の比 較には，对応のある $\mathrm{t}$ 検定を行った。

\section{(2) 実験結果}

図11に酸素化へモグロビン濃度変化量, 脱酸素化へモグロビン濃 度変化量, 総へモグロビン濃度変化量を示す。

左額において測定した酸素化へモグロビン濃度および総へモグロ ビン濃度の増加量は, ポジショニング作業, テキストタイピング作 業および $\mathrm{PAB}$ 作業において, 作用温度 $33^{\circ} \mathrm{C}$ 条件の方が $25^{\circ} \mathrm{C}$ 条件よ $\eta$ も有意に大きかった $(\mathrm{p}<0.01)$ 。被験者が人工気候室内に入室し, 椅座位安静状態で25分経過した時点から, 全てのパソコン作用が終 了するまでのデータの平均値をみると, 作用温度 $33^{\circ} \mathrm{C}$ 条件下では, 酸素化へモグロビン濃度変化の平均は, 左額側で+2.65 $\mu \mathrm{M}$, 右額側
で+2. $47 \mu \mathrm{M}$, 総へモグロビン濃度変化量の平均は, 左脳側で +1.71 $\mu \mathrm{M}$, 右脳側で+1.68 $\mu \mathrm{M}$ であり，堌加側の值となった。一方，作用 温度 $25^{\circ} \mathrm{C}$ 条件下では, 酸素化へモグロビン濃度変化の平均は, 左額 側でー $3.91 \mu \mathrm{M}$, 右額側で- $1.26 \mu \mathrm{M}$, 総へモグロビン濃度変化量の 平均は, 左額側で- $5.25 \mu \mathrm{M}$, 右額側でー $2.52 \mu \mathrm{M}$ であり, 減少側の 值となった。

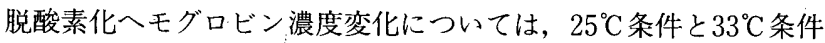
との間に有意な差は認められなかった。脱酸素化へモグロビン濃度 変化の平均は, $33^{\circ} \mathrm{C}$ おび $25^{\circ} \mathrm{C}$ 条件ともに減少側の值だった。

既往の研究より，暗算作業や鏡映描写作業などの精神作業負荷時 に，酸素化へモグロビンの増加，脱酸素化へモグロビンの減少，お よび総へモグロビンの増加が, 典型的に認められると報告されてい る $^{24), 25)}$ 。本研究の $33^{\circ} \mathrm{C}$ 条件における結果は, 精神作業時に典型的に生 じると報告されている脳内酸素代謝の状態と一致している。ただし，

表 8 実験環境条件（練習条件除く）

\begin{tabular}{c|c|c|c|c}
\hline & $\begin{array}{c}\text { Air Temp. } \\
{[\mathrm{C}]}\end{array}$ & $\begin{array}{c}\text { Globe Temp. } \\
{\left[{ }^{\mathrm{C}}\right]}\end{array}$ & $\begin{array}{c}\text { Operative } \\
\text { Temp. } \\
{[\mathrm{C}]}\end{array}$ & $\begin{array}{c}\text { Relative } \\
\text { Humidity } \\
{[\%]}\end{array}$ \\
\hline $25^{\circ} \mathrm{C}$ & 25.1 & 25.2 & 25.2 & 45 \\
& $(0.41)$ & $(0.44)$ & $(0.43)$ & $(0.4)$ \\
\hline $33^{\circ} \mathrm{C}$ & 33.0 & 33.2 & 33.1 & 44 \\
& $(0.33)$ & $(0.20)$ & $(0.24)$ & $(0.9)$ \\
\hline
\end{tabular}

表 9 被験者の身体的特徴

\begin{tabular}{c|c|c|c|c|c|c}
\hline Sex & $\begin{array}{c}\text { Num } \\
\text { ber }\end{array}$ & Age & $\begin{array}{c}\text { Hei } \\
\text { ght } \\
{[\text { year] }}\end{array}$ & $\begin{array}{c}\text { Wei } \\
\text { ght } \\
{[\mathrm{cm}]}\end{array}$ & $\begin{array}{c}\text { Body } \\
\text { Surface } \\
\text { Area } a^{\dagger 1} \\
{\left[\mathrm{~m}^{2}\right]}\end{array}$ & $\begin{array}{c}\text { Rohrer } \\
\text { Index } \\
{[-]}\end{array}$ \\
\hline Male & 6 & $\begin{array}{c}22.8 \\
(0.75)\end{array}$ & $\begin{array}{c}169.3 \\
(4.13)\end{array}$ & $\begin{array}{c}58.5 \\
(9.12)\end{array}$ & $\begin{array}{c}1.68 \\
(0.13)\end{array}$ & $\begin{array}{c}119.9 \\
(13.4)\end{array}$ \\
\hline
\end{tabular}

${ }^{\dagger 1}$ Caluculated by Takahira's Equation $\mathrm{A}=72.46 \mathrm{~W}^{0.425} \times \mathrm{H}^{0.725}$

${ }^{\dagger 2}$ Rohrer Index $=\mathrm{W} / \mathrm{L}^{3} \times 10^{7} （ ）$ standard deviation

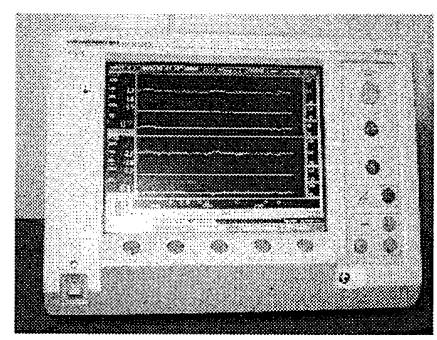

(データ表示部)
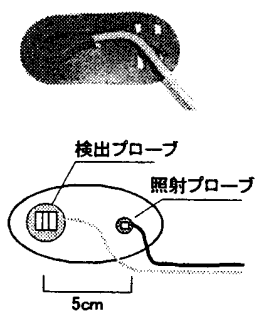

（測定プロープ）

图 9 近赤外線酸素モニ夕 NIRO-300
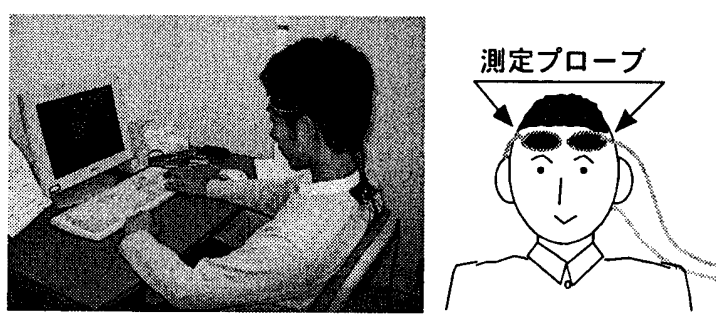

図10被験者実験風景 

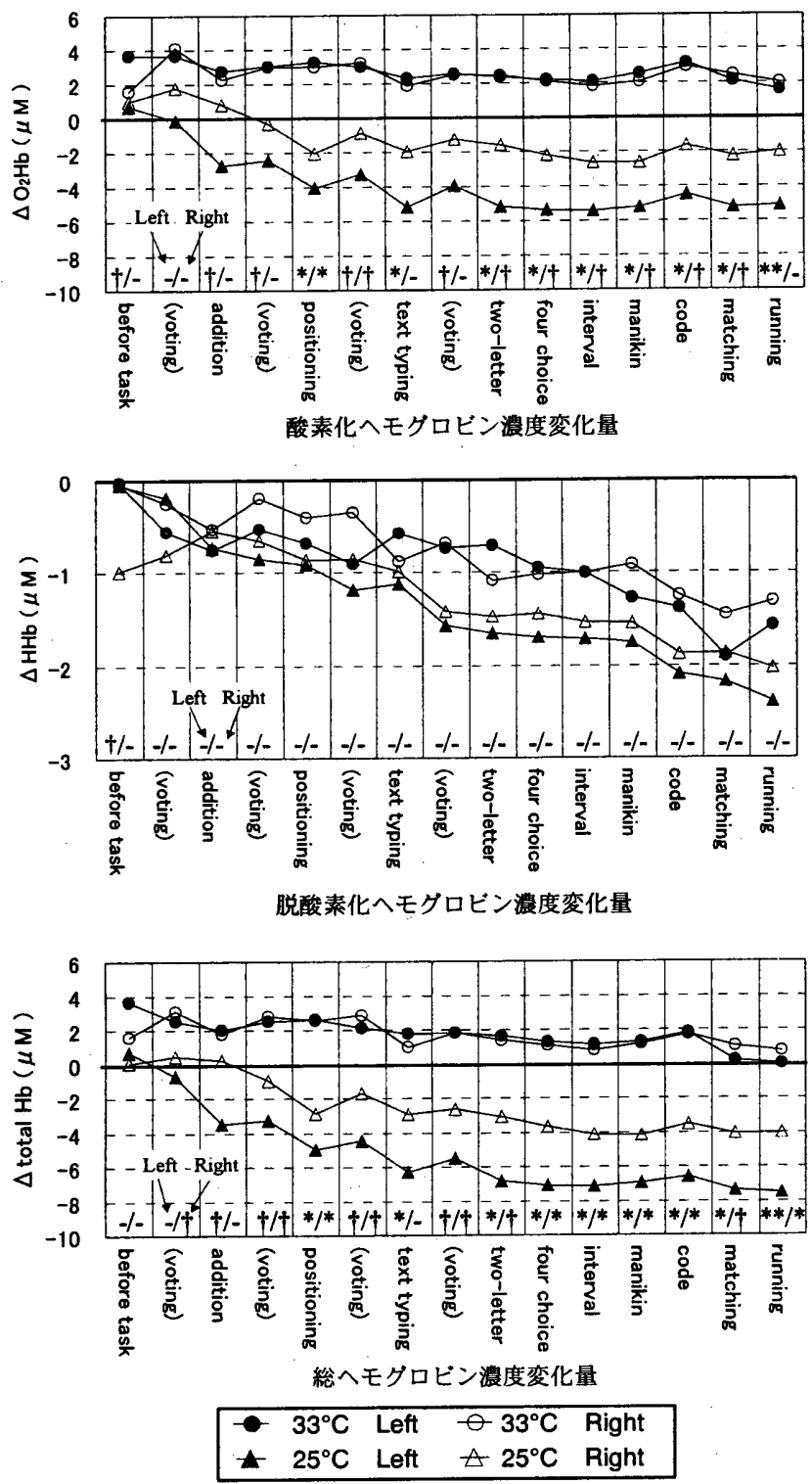

About each left and right side of cerebral hemoglobin concentration, the results of paired t-test between $25^{\circ} \mathrm{C}$ and $33^{\circ} \mathrm{C}$ during each task are shown. (-: no significant. $\left.\dagger: p<0.1,{ }^{*}: p<0.05,{ }^{* *}: p<0.01\right)$

\section{図11 脳内酸素代謝状態}

体温調節による脳内酸素代謝に関しての区別が今後必要であろう。 また，作用温度が $33^{\circ} \mathrm{C} の$ 条件では，自覚症状しらべにより精神作業・ 夜勤型の疲労感が生じ，脳内酸素代謝も精神作業時に典型的な状態 となった。脳内酸素代謝状態の変動と, 疲労感が関連する可能性が 考えられる。

\section{5.まとめ}

本研究では, 中程度の高温環境が知的生産性に与之る影響を調べ ることを目的とし，作用温度 $25.5,28 ， 33^{\circ} \mathrm{C}$ に制御した人工気候室 内で被験者実験を行った。その結果, 以下のことが明らかとなった。

1) 実験室の作用温度が高くなるにつれ，空気の新鮮度についての 主観申告值は有意に低下し，「むっとする」側の申告となった。

2 ）作業量については, 男性に関し, テキストタイピングと Four choice 以外の作業では，条件間に有意な差が認められなかった。
また，女性については全ての作業課題において条件間に有意差が 認められなかった。男性のテキストタイピングでは $25.5^{\circ} \mathrm{C}$ 条件が $28,33^{\circ} \mathrm{C}$ 条件よりも作業量が少なく, Four choice では $33^{\circ} \mathrm{C}$ 条件が $28^{\circ} \mathrm{C}$ 条件よりも作業量が少なかった。

3 ）「自覚症状しらべ」を用い，疲労感の測定を行った。作業環境の 作用温度が熱的中立状態より高温になることにより，自覚症状の 総合訴之率が高くなった。作用温度 $33^{\circ} \mathrm{C}$ 条件では，精神作業・夜 勤型の疲労感が生じることが明らかとなった。

4 ）作用温度 $33^{\circ} \mathrm{C}$ 条件において, 酸素化へモグロビン濃度の增加, 脱酸素化へモグロビン濃度の減少, 総へモグロビン濃度の増加と いう精神作業時に典型的な脳内酸素代謝の状態が認められた。

5 ）中程度の高温環境が知的生産性に与える影響を評価する上で, 作業成績による評価だけでなく，疲労を測定することが重要であ ることが示唆された。

\section{謝辞}

本研究にご協力頂いた山本ゆう子様に感謝致します。被験者とし てご参加下さった方々へ心より御礼申し上げます。なお，本研究の 一部は科学研究費 (基盤研究(A)(2)課題番号14205085), 笹川科学研究 助成, および日本建築学会「シックハウス問題の解明とへルシーな 居住環境の開発」特別研究委員会（村上周三委員長）により実施し た。ここに記し，感謝の意を表します。

注釈

統計的に有意な差があるという事と，その差が実質上意味のある差であると いう事とは, 必ずしも一致しない。温熱環境と生産性の研究は, 従来から行わ れてはいるものの，明確な結論が得られていないのが現状である。作業成績で どのくらいの差異があった場合に, 生産性に影響が出るのかについては, 現状 ではまだ充分な知見が少なく，実質上意味のある作業成績の差を設定しておく ことが困難である。本論文では, 温熱環境と生産性の関係を評価する手法を検 討することを目的としている。そのため研究の第一段階として,「温熱環境条 件間で，測定值の平均に差があるかどうか」という，統計的な有意差があるか どうかという点にのみに注目し結果を検討した。なお，群間の平均值に本来差 がない場合に，これを叀却してしまう「第一の過誤」を犯导確率は，有意水準 の設定や $\mathrm{p}$ 值の記述によって明示することができる。一方, 群間の平均值に本 来差がある場合に，帰無仮説を採択する「第二の過誤」を犯す確率を明確にす るには，一般的には検出力を示すという方法がとられる。この検出力の算出に あたっては, 標本デー夕数と, 実質的に重要と考えられる差を事前に設定して おく必要がある。この「実質的に重要と考えられる差」については，生産性の 研究において定義できるほどの知見が蓄積されていないと考えられ, 検出力を 算出することは現状では困難である。従って，本論文では，㷌無仮説を妄却で きるかどうかという検定を行いももし菓却できない場合にはこれを積極的に採 択することのないよう留意し記述を行った。

\section{参考文献}

1) 佐藤方彦：オフィス・アメニティ, 井上畫院, 東京, 1989

2) United States Environmental Protection Agency, Indoor Environments Division: Indoor Air Quality and Student Performance, EPA 402-F-00-009, 2000

3) Parsons, K. : Human Thermal Environment, London, UK : Taylor \& Francis, pp.199-217, 1993

4) Dorgan, C.B., C.E. Dorgan, M.S. Kanarek, A.J. Willman: Health and Productivity Benefits of Improved Indoor Air Quality, ASTHAE Trans, 98, (1A), pp.658-665, 1998

5) Fisk, W., Rosenfeld, A.: Estimates of improved productivity health from better indoor environments, Indoor Air, 7, pp.158-172, 1997

6) Wyon, D.P., Fisk, W., Rautio, S. Research needs and approaches pertaining to the indoor climate and productivity, Healthy Buildings 
2000 Workshop Summaries, pp.1-8, 2000

7) Heath, G.A., and M.J. Mendell : Do Indoor Environments in Schools Influence Student Performance? A Review of the Literature, Proceedings of Indoor Air 2002, pp.802-807, 2002

8) Vernon, H.M.: The influence of hours of work and of ventilation on output in tinplate manufacture, Report to Industrial Fatigue Research Board, No. 1, London: HMSO, 1919

9) Chrenko, F.A. (Ed.) : Bedford's Basic Principles of Ventilation and Heating, 3rd eds. (H.K. Lewis, London), 1973

10) Wyon, D.P.: The effects of indoor climate on productivity and performance: a review, WS and Energi, 3, 59-65, 1986

11) Lorsch, H.G., O.A. Abdou: The impact of the indoor environment on occupant productivity - Part 2: Effects of temperature, ASHRAE Transactions, 100(2), pp.895-901, 1994

12) Sundstrom, E. : Work environments: offices and factories, Handbook of environmental psychology, Vol. 1, Eds. Stokols, D., and Altman I, Chapter 19 (New York: John Wiley), pp.733-782, 1987

13) McIntyre, D.A.: Temperature and performance, Indoor climate Chapter 11 (London: Applied Science), pp.346-371, 1980

14）吉竹 博：改訂産業疲労一自覚症状からのアプローチー, 財団法人労働科 学研究所出版部, 1993

15）中村直人：近赤外分光装置とその応用, 日本生理人類学会誌, Vol. 1, No. 2, pp.111-114, 1996

16）宮崎良文, 森川 岳, 伊藤幸恵, 山本 昇, 中田知里, 富田文一郎：木材 の香りが生体に及ぼす影響 (II) 一脑血流量を指標として一, 第49回日本木 材学会大会研究発表要旨集, pp.184, 1999

17）森川 岳, 末吉修三, 宮崎良文：塗装した木材への接触が生体に及ばす影 響 (II)一血圧ならびに脸血流量を指標として一,第49回日本木材学会大会
研究発表要旨集, pp.185, 1999

18）田辺新一,長谷部ヤエ：皮䖉温度可変型サーマルマネキンによる室内環境 評価法に関する研究，日本建築学会計画系論文報告集，448, pp.1-8, 1993

19) Thorne, D.R., Genser, S.G., Sing H.C. and Hegge F.W.: The Walter Reed Performance Assessment Battery. Ankho International Inc. Printed in the U.S.A., Neurobehavioral Toxicology and Teratology, Vol. 7, pp.415-418, 1985

20）酒井一博：日本産業衛生学会産業疲労研究会撰「自覚症しらべ」の改訂作 業2002, 労働の科学, 57(5), pp.27-30, 2002

21) Pepler R.D. and Warner R.E.: Temperature and Learning: An Experimental Study, ASHRAE Trans., Vol. 74(2), pp.211-224, 1968

22) CIBSE : Environmental factors affecting office worker performance: A review of evidence CIBSE Technical Memoranda TM24, Windsor, Berks : Reedprint Limited, 1999

23) Delpy D.T., Cope M., van der Zee P, Arrige S, Wray S, Wyatt J. : Estimation of optical pathlength through tissue from direct time of flight measurement, Phys Med Biol, Vol. 33, pp.1433-1442, 1988

24）木戸眞美：近赤外線吸収で測る精神作用，医用電子と生体工学，Vol. 33, 特別号, pp.357, 1995

25) Villringer A, Planck J, Hock C, et al.: Near infrared spectroscopy (NIRS) : a new tool to study hemodynamic changes during activation of brain function in human adults, Neuroscience Letters, Vol. 154, pp. 101-104, 1993

（2002年11月 5 日原稿受理，2003年 4 月 1 日採用決定） 